\title{
Phosphorus fertilizer for lettuce grown in Ultisol in the state of Maranhão
}

\section{Adubação fosfatada para alface cultivada em Argissolo no Estado do Maranhão}

\section{Alexsandra Souza Nascimento da SILVA ${ }^{1,2}$; Arthur Bernardes CECILIO FILHO ${ }^{3}$; Sandra Maria Cruz NASCIMENTO2; Pablo Forlan VARGAS ${ }^{4}$}

${ }_{1}^{1}$ Parte da tese de doutorado do primeiro autor

${ }^{2}$ Doutora, IFMA - Campus Maracanã, Av. dos Curiós, S/N - Vila Esperança - São Luís-MA - CEP 65095-460; alexsandra.nascimento@ifma.edu.br; scostacruz@bol.com.br

${ }^{3}$ Doutor, Faculdade de Ciências Agrárias e Veterinárias, UNESP - Universidade Estadual Paulista, Campus de Jaboticabal, Departamento de Produção Vegetal. Rod. Prof. Paulo D. Castellane s/n, 14884-900, Jaboticabal-SP; rutra@fcav.unesp.br

${ }^{4}$ Autor para correspondência - Doutor, UNESP - Universidade Estadual Paulista, Campus de Registro, Coordenadoria de Curso Agronomia. Rua Nelson Brihi Badur, 430, Vila Tupy, 11900-000, Registro-SP; pablo@registro.unesp.br

Recebido em: 05-11-2014; Aceito em: 06-10-2015

\begin{abstract}
The use of mineral fertilizers in lettuce is an agricultural practice that brings satisfactory results, however, one must know the optimal dose according to each soil type and its fertility. Thus, the objective was to evaluate the influence of phosphorus doses on the production of lettuce 'Vera', in soil with low phosphorus content $\left(14 \mathrm{mg} \mathrm{dm}^{-3}\right)$. The experiment was conducted from September 3 to October 18, 2011. The experimental design was randomized blocks, with six treatments $\left(0,50,100,200,300\right.$ and $\left.400 \mathrm{~kg} \mathrm{ha}^{-1} \mathrm{P}_{2} \mathrm{O}_{5}\right)$ and four replications. The $\mathrm{P}$ content in the soil and leaf showed quadratic adjustments and increased with $\mathrm{P}$ supply up to 320 and $205 \mathrm{~kg} \mathrm{ha}^{-1} \mathrm{P}_{2} \mathrm{O}_{5}$, respectively. The fresh mass of shoots and dry mass of shoots and $\mathrm{P}$ accumulation also showed quadratic adjustment. The highest fresh mass of shoots and dry mass of shoots were obtained with doses of 283 and $292 \mathrm{~kg} \mathrm{ha}^{-1}$ of $\mathrm{P}_{2} \mathrm{O}_{5}$, respectively. The accumulation of $P$ for the lettuce with a dose that maximized fresh mass of shoots was $127 \mathrm{mg} \mathrm{plant}^{-1}$, or $8.8 \mathrm{~kg} \mathrm{ha}^{-1} \mathrm{P}$, or $20 \mathrm{~kg} \mathrm{ha}^{-1} \mathrm{P}_{2} \mathrm{O}_{5}$.
\end{abstract}

Additional keywords: economic dose; Lactuca sativa; productivity.

\section{Resumo}

A utilização de fertilizantes minerais na alface é uma prática agrícola que traz resultados satisfatórios, porém é necessário saber qual a dose ótima de acordo com cada classe de solo e sua fertilidade. Assim, o objetivo foi avaliar a influência de doses de fósforo à produção de alface 'Vera', em solo com baixo teor de fósforo $\left(14 \mathrm{mg} \mathrm{dm}^{-3}\right)$. $\mathrm{O}$ experimento foi realizado de 3 de setembro a 18 de outubro de 2011. O delineamento experimental utilizado foi o de blocos casualizados, com seis tratamentos $\left(0 ; 50 ; 100 ; 200 ; 300\right.$ e $400 \mathrm{~kg} \mathrm{ha}^{-1}$ de $\left.\mathrm{P}_{2} \mathrm{O}_{5}\right)$ e quatro repetições. $\mathrm{O}$ teor de $\mathrm{P}$ no solo e na folha apresentou ajustes quadráticos e aumentou com o fornecimento de $\mathrm{P}$ até 320 e $205 \mathrm{~kg} \mathrm{ha}^{-1}$ de $\mathrm{P}_{2} \mathrm{O}_{5}$, respectivamente. A massa fresca da parte aérea e a massa seca da parte aérea e 0 acúmulo de $P$ também apresentaram ajuste quadrático. A maior massa fresca da parte aérea e a massa seca da parte aérea foram obtidas com as doses de 283 e $292 \mathrm{~kg} \mathrm{ha}^{-1}$ de $\mathrm{P}_{2} \mathrm{O}_{5}$, respectivamente. $O$ acúmulo de $P$ pela alface com uma dose que maximizou massa fresca da parte aérea foi de $127 \mathrm{mg}_{\text {planta-1 }}$, ou $8,8 \mathrm{~kg} \mathrm{ha}^{-1}$ de $\mathrm{P}$, ou $20 \mathrm{~kg} \mathrm{ha}^{-1}$ de $\mathrm{P}_{2} \mathrm{O}_{5}$.

Palavras-chave adicionais: dose econômica; Lactuca sativa; produtividade.

\section{Introduction}

Lettuce (Lactuca sativa L.) is the most popular leafy vegetable in Brazil (Petrazzini et al., 2014). The consumption usually occurs in natura, and has intensified in recent years by the population growth and the demand for a healthier diet (Villas Bôas et al., 2004). Among the various existing groups in the Brazilian market, it is highlighted the cultivation of lettuce of the group "Crespa" (Crisp leaf), with a participation percentage of $61 \%$ (Tosta et al., 2009).

The use of mineral fertilizers in lettuce is an agricultural practice that brings satisfactory results in terms of productivity. Nonetheless, one should take into account the final quality of the product, because the excess use can harm the health of consumers, burden the cost of production (Souza et al., 2005) and negatively impact the environment.

In the United States, country with large consumption and therefore great exploration of the culture, several studies have been developed to increase and improve production, especially with regard to nitrogen and phosphorus fertilization (Johnstone et al., 2005; Hartz \& Johnstone, 2007). Both the high costs of production and the concern for the environment, with regard to the accumulation of elements in the soil, 
have justified the development of research to maximize the production and quality of the crop and minimize negative impacts (Hochmuth et al., 2009).

With regard to phosphorus fertilization, Faquin \& Andrade (2004) report its importance for the enzymatic metabolism of the plant. In addition, the nutrient interferes with the growth thereof and, in some cultivars, deficiency causes malformation of the head (Mota et al., 2003).

Almeida et al. (2011) found that lettuce plants not fertilized with phosphorus had decreased leaf area and number of leaves, with consequent reduction in dry matter (shoots and roots) and production.

In tropical soils, the phosphorus concentration is naturally low, as is also low its availability due to the high fixation potential. Whereas the lettuce is a culture with high demand of phosphorus, especially in the final phase of its cycle (Lana et al., 2004), it is necessary to conduct studies in the different edaphoclimatic conditions of the country for proper nutritional management. For the state of Maranhão, there are no studies that support recommendation of phosphorus levels for lettuce.

In this light, the aim of this study was to evaluate phosphorus levels in the production of lettuce in soil with low content of phosphorus in the state of Maranhão.

\section{Material and methods}

The experiment was carried out from September 3 to October 18, 2011, at the Maracanã Campus IFMA - São Luis, MA, located 2³6'35,94" South, 44ำ15'52,02" West, and altitude of 34 meters.

The climate, according to Thornthwaite classification, is the type B1 WA, characterized as humid, with moderate water deficiency in the winter, between the months of June and September. The annual average temperature is $27^{\circ} \mathrm{C}$, with average annual rainfall of $2000 \mathrm{~mm}$. The soil where cultivation was held is an Ultisol (EMBRAPA, 2013).

The chemical and textural characteristics of the soil were measured previous to the installation of the experiment, with soil samples collected in the $0-20 \mathrm{~cm}$ layer. These samples were sent to the Laboratory of Chemistry and Fertility of the Soil from the State University of Maranhão. The analysis showed a soil texture with 60,80 and $860 \mathrm{~g} \mathrm{~kg}^{-1}$ clay, silt and sand, respectively. Chemical analysis showed: $\mathrm{pH}\left(\mathrm{CaCl}_{2}\right)$ 4.8; $14 \mathrm{~g} \mathrm{dm}^{-3}$ Organic matter; $14 \mathrm{mg} \mathrm{dm}^{-3} \mathrm{P}$ (resin); $\mathrm{K}, \mathrm{Ca}, \mathrm{Mg}, \mathrm{Al}+\mathrm{H}$ and CEC were, respectively, 0.3, 3.0, 4.0, 24.0, $31.7 \mathrm{mmol}_{\mathrm{c}} \mathrm{dm}^{-3}$ and $24 \%$ base saturation.

Based on the results of the chemical analysis of the soil, it was held liming, using limestone with 98\% PRNT (32\% $\mathrm{CaO}$ and 15\% MgO), with 30 days in advance, to raise the soil base saturation to $80 \%$ (Trani et al., 1997). Subsequently, it was carried out plowing and harrowing for incorporation of the lime. After 30 days, the planting beds were prepared with the aid of rotavator-bed former.

The fertilization was performed in accordance with the recommendation of Trani et al. (1997), except for $\mathrm{P}$. The soil of the planting beds received, three days before transplanting the seedlings, $60 \mathrm{t} \mathrm{ha}^{-1}$ tanned cattle manure, $40 \mathrm{~kg} \mathrm{ha}^{-1} \mathrm{~N}$, in the form of urea, and $150 \mathrm{~kg} \mathrm{ha}^{-1} \mathrm{~K}_{2} \mathrm{O}$, in the form of potassium chloride.

The experiment was conducted in a randomized block design, with six treatments $(0,50,100$, 200,300 and $400 \mathrm{~kg} \mathrm{ha}^{-1} \mathrm{P}_{2} \mathrm{O}_{5}$ ), in the form of triple superphosphate, and four replications. The plots were $3.0 \mathrm{~m}$ long by $1.0 \mathrm{~m}$ wide, containing four lettuce rows, spaced $0.25 \times 0.25 \mathrm{~m}$, totaling 48 plants. It were considered as useful area of the plot, for data collection, the eight central plants of the two central rows.

It was used the cv. 'Vera', from crisp leaf group, chosen for its good acceptance in the local market, and for the good results obtained in assessment tests of cultivars in the region.

The seedlings were grown in the nursery of the Agriculture Sector I of IFMA, Maracanã Campus, in São Luís, MA, in polypropylene trays with 128 cells, filled with commercial substrate Plantmax $H A \AA$. Sowing was performed by placing two pelleted seeds per cell. After sowing, the trays were covered with a thin layer of the substrate. Approximately seven days after seedling emergence was carried out the thinning, leaving one plant per cell. The water supply in the nursery period was made twice a day. The transplant was performed when the seedlings had four full leaves, 21 days after sowing.

In coverage fertilizations were applied $90 \mathrm{~kg}$ ha $^{-1} \mathrm{~N}$ (urea), amount divided equally in three plots, 10 , 20 and 30 days after transplantation (DAT) (Trani et al., 1997). Every week, the plants were sprayed with calcium nitrate, with $2.5 \mathrm{~g} \mathrm{~L}^{-1}$ diluted in $400 \mathrm{~L} \mathrm{ha}^{-1}$ broth.

Irrigation was performed by localized system, tube dripper, being one tube dripper for every two rows of plants, with drippers spaced at $0.30 \times 0.30 \mathrm{~m}$.

As for the control of weeds during the experiment were adopted technical recommendations for the lettuce, being it performed weekly by the manual method. It was not found the occurrence of phytosanitary problems over cultivation, with no need for intervention.

During the crop cycle, the leaf content of $P$ (PL) was assessed, following the recommendation of Trani \& Raij (1997). When the plants reached approximately two-thirds of the estimated cycle, sampling of newly developed leaves was carried out, the collection being carried out early in the morning. Once collected, the leaves were sent to the Laboratory and washed with tap water and deionized water. After the removal of excess water with a paper towel, the samples were placed in paper bags, identified and taken to drying in an oven with forced air circulation at $65^{\circ} \mathrm{C}$ until constant mass. Then, each sample was ground in a Wiley mill. The preparation of the extract to read the leaf content of $P$ was performed according to Bataglia et al. (1983). 
Harvest was held at 45 days after transplantation, when the plants were completely developed in their vegetative part. So the following characteristics were evaluated: a) Fresh mass of shoots (FMS): the cutting of stem held close to the soil surface. The dead and senescent leaves were discarded and the mass determined with the aid of $0.01 \mathrm{~g}$ precision balance. b) Dry mass of shoots (DMS): the shoots of the evaluated plants were dried in an oven with forced circulation at $65^{\circ} \mathrm{C}$, until constant weight. After drying, they were weighed on an electronic scale with accuracy of two decimal places $(0.01 \mathrm{~g})$. c) P content in the soil (PS): after the end of the experiment, soil samples were collected from each plot, in the layer $0-20 \mathrm{~cm}$ deep, to determine the values of available P. Prior to sampling, it was carried out the homogenization of the plot bed and then eight simple samples were collected to make up a plot sample. The samples were sieved and put to dry in the shade. They were then taken to the laboratory of soils, from UEMA, to determine the nutrient content using the methodology described by Raij (1991). d) P accumulation ( $\mathrm{mg} \mathrm{plant}^{-1}$ ): obtained by multiplying the $P$ content in the DMS and the cumulative amounts of DMS.

Analysis of variance ( $\mathrm{F}$ test) was performed according to the proposed design, and polynomial regression analysis, opting for significant equation of higher degree. The statistical program AGROESTAT was used.

\section{Results and discussions}

P doses applied influenced all evaluated traits. There was a quadratic regression adjustment for all measured characteristics (DMS) (Table 1).

Table 1 - Analysis of variance, means and polynomial regression study for $\mathrm{P}$ content in the soil (PS), P content in leaf (PL), fresh mass of shoots (FMS), dry mass of shoots (DMS) and phosphorus accumulation $(\mathrm{P})$ in plants of lettuce 'Vera' depending on levels of phosphorus.

\begin{tabular}{lccccc}
\hline Source of variation & $\begin{array}{c}\mathrm{PS} \\
\left(\mathrm{mg} \mathrm{dm}^{-3}\right)\end{array}$ & $\begin{array}{c}\mathrm{PL} \\
\left(\mathrm{g} \mathrm{kg}^{-1}\right)\end{array}$ & $\begin{array}{c}\mathrm{FMS} \\
\left(\mathrm{g} \mathrm{plant}^{-1}\right)\end{array}$ & $\begin{array}{c}\text { DMS } \\
\left(\mathrm{g} \mathrm{plant}^{-1}\right)\end{array}$ & $\begin{array}{c}\mathrm{P} \\
\left(\mathrm{mg} \mathrm{plant}^{-1}\right)\end{array}$ \\
\hline Treatments & $10.59^{* *}$ & $6.30^{* *}$ & $\begin{array}{l}\mathrm{F} \mathrm{Value} \\
40.23^{* *}\end{array}$ & $56.26^{* *}$ & $34.84^{* *}$ \\
\hline P level & & & & \\
$\left(\mathrm{kg} \mathrm{ha}^{-1} \mathrm{P}_{2} \mathrm{O}_{5}\right)$ & & & Means & & \\
0 & 21 & 4.5 & 102.00 & 2.89 & 15.43 \\
50 & 40 & 4.5 & 433.75 & 8.69 & 66.99 \\
100 & 45 & 6.0 & 565.50 & 11.24 & 106.45 \\
200 & 57 & 6.7 & 824.25 & 15.17 & 117.36 \\
300 & 55 & 5.5 & 774.25 & 15.74 & 113.38 \\
400 & 61 & 4.5 & 770.25 & 15.13 & 102.89 \\
\hline Regression & & & $\mathrm{F}$ Value & \\
$1^{\text {st }}$ degree & $41.11^{* *}$ & $0.32^{\mathrm{NS}}$ & $137.08^{* *}$ & $206.40^{* *}$ & $116.71^{* *}$ \\
$2^{\text {nd }}$ degree & $8.23^{*}$ & $25.50^{* *}$ & $56.79^{* *}$ & $70.76^{* *}$ & $103.75^{* *}$ \\
\hline C.V.(\%) & 19.45 & 14.52 & 15.10 & 11.67 & 13.08 \\
\hline
\end{tabular}

${ }^{* *}$ significant at $1 \%$ probability; * significant at $5 \%$ probability; ${ }^{\text {ns }}$ non-significant at $5 \%$ probability

There was an increase in the $P$ content in the soil, from 14 to $21 \mathrm{mg} \mathrm{dm}^{-3} \mathrm{P}$, in the treatment without addition of $P$ at planting, which may have occurred due to two factors: the $P$ from the organic fertilizer and the correction of soil pH (Lana et al., 2004; Souza et al., 2006), which provided $P$ that was previously unavailable. With doses of 50,100,200, 300 and $400 \mathrm{~kg} \mathrm{ha}^{-1} \mathrm{P}_{2} \mathrm{O}_{5}$, the $\mathrm{P}$ content available in the soil increased $2.9 ; 3.2 ; 4.1 ; 3.9$ and 4.4 times in relation to the $\mathrm{P}$ content in the soil before fertilization. According to Coutinho et al. (2008), one of the main factors for the increase in availability of $P$ in the soil is the nutrient supply via fertilization. Notwithstanding, the increased availability of $\mathrm{P}$ may also have been favored by the management given to culture, in this case specifically referring to the liming and organic fertilization. Souza et al. (2006) observed that the addition of cattle manure and limestone increased the values of remaining $P$ and of the $P$ buffer index, and reduced the maximum capacity of adsorption of the nutrient. An explanation for this fact is that carboxylic and phenolic functional groups present in the organic matter are responsible for blocking the positively charged sites of $\mathrm{Fe}$ and $\mathrm{Al}$ oxides, reducing the adsorption of $\mathrm{P}$ (Guppy et al., 2005). The increase in the soil $\mathrm{pH}$ by liming, increasing the concentration and activity of $\mathrm{OH}^{-}$ions in solution, promotes the precipitation of $\mathrm{Al}$, which reduces the formation of poorly soluble compounds of these elements (P-Al) (Souza et al., 2006).

The leaf $P$ content was significantly influenced by doses of $P$ and the model that best adjusted the observed averages was the quadratic. However, it was found that the leaf $P$ content showed no corresponding increase observed for the $\mathrm{P}$ content in soil (Figure 1). A well-nourished lettuce plant has 
values considered appropriate in the range of 4.0 to $7.0 \mathrm{~g} \mathrm{~kg}^{-1}$ phosphorus (SBCS, 2004). Hence, it appears that the values found for the leaf content of $P$ (4.5 to $6.7 \mathrm{~g} \mathrm{~kg}^{-1}$ ) are within the range for all doses of
P applied to the soil. Nonetheless, these amounts are very general indications, as the plant-environment interaction can influence the levels increasing them or decreasing them.

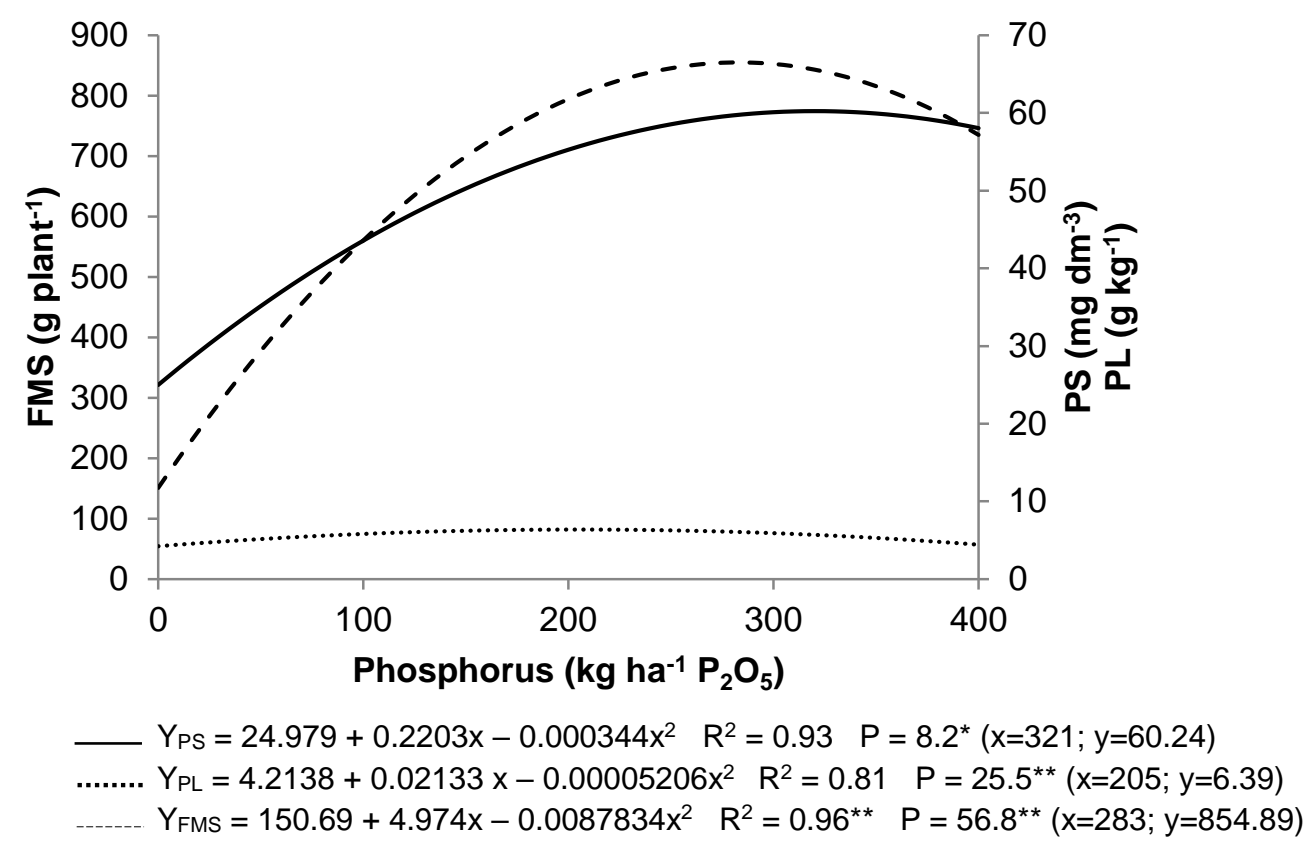

Figure 1 - Fresh mass of shoots (FMS), phosphorus leaf content (PL) and $\mathrm{P}$ content in the soil (PS) depending on levels of phosphorus in lettuce 'Vera'.

The leaf content of $\mathrm{P}$ observed in plants unfertilized with phosphorus was $4.5 \mathrm{~g} \mathrm{~kg}^{-1}$. With supply of $\mathrm{P}$, the leaf content of $\mathrm{P}$ increased up to the dose of $205 \mathrm{~kg} \mathrm{ha}^{-1} \mathrm{P}_{2} \mathrm{O}_{5}\left(6.4 \mathrm{~g} \mathrm{~kg}^{-1}\right)$. Larger doses provided reductions in leaf $\mathrm{P}$ content, and with $400 \mathrm{~kg} \mathrm{ha}^{-1} \mathrm{P}_{2} \mathrm{O}_{5}$ was found content of $4.4 \mathrm{~g} \mathrm{~kg}^{-1}$, close to that verified without $P$ fertilization (Figure 1). There is, therefore, decreasing $\mathrm{P}$ content in the tissues of lettuce after the point of inflection of the curve $\left(6.4 \mathrm{~g} \mathrm{~kg}^{-1}\right)$. This was due to the growth rate of the dry mass (Figure 2) of the plant exceeding the nutrient absorption rate, i.e. there was a nutrient dilution effect in the tissues.

All leaf contentes of $P$, regardless of the $P$ level applied, stood in the range of appropriate levels for lettuce, which according to Trani \& Raij (1997) is 4-7 $\mathrm{g} \mathrm{kg}^{-1}$, not being found visual symptom of $P$ deficiency or toxicity in the treatments.

Unlike observed in the present study, Coutinho et al. (2008), in a Yellow Red Latosol with low $P$ content, found values between 2 (without $P$ fertilization) and $7 \mathrm{~g} \mathrm{~kg}^{-1} \mathrm{P}$ for three lettuce cultivars, and even found visual symptom of deficiency in the nutrient at zero dose. Yet Mógor \& Câmara (2009), evaluating the effect of soil cover with straw, on leaf contents of $\mathrm{P}$ and $\mathrm{K}$, found that lettuce 'Veronica' showed an average content of $4.0 \mathrm{~g} \mathrm{~kg}^{-1} \mathrm{P}$ in plants grown in soil with average content of $P$ and fertilized with $1500 \mathrm{~kg} \mathrm{ha}^{-1}$ thermophosphate.
The non-checking of $\mathrm{P}$ deficiency symptoms on lettuce plants, even in the treatment without application of the nutrient, can be due to its stock in the soil, which was able to meet the plant's needs, even with soil presenting content considered low $\left(14 \mathrm{~g} \mathrm{dm}^{-3}\right)$ before the implementation of the study. Allied to the above, soil liming took place 30 days prior to implantation of the culture, and this fact contributed to increase the availability of $P$ for plants, because liming reduces the losses by phosphorus adsorption by iron and aluminum (Luchini et al., 2012), and the organic fertilization with $60 \mathrm{t} \mathrm{ha}^{-1}$ of cattle manure.

In studies conducted by Bonela (2010), evaluating the response of lettuce cultivars to doses of $P$, in soil with high $P$ content, found that 'Amanda', from the crisp leaf group, presented $3.9 ; 4.5 ; 4.7$; $3.6 \mathrm{~g} \mathrm{~kg}^{-1}$ leaf $P$ at doses of $0,100,200$ and $300 \mathrm{~kg} \mathrm{ha}^{-1} \mathrm{P}_{2} \mathrm{O}_{5}$, respectively, values which are close to those found in this study. However, the studies differ in the initial fertility of the soil in $\mathrm{P}$.

The maximum FMS (855 $\left.\mathrm{g} \mathrm{plant}^{-1}\right)$ and DMS (16.5 g plant ${ }^{-1}$ ) of lettuce 'Vera' were obtained with 283 and $292 \mathrm{~kg} \mathrm{ha}^{-1}$ of $\mathrm{P}_{2} \mathrm{O}_{5}$, respectively (Figures 1 and 2). According to Raij (1991), adequate amounts of $P$ in the soil favorably influence the production of the crops, since the $\mathrm{P}$ stimulates root development and enhances the opportunities of nutrient uptake by the plant. 


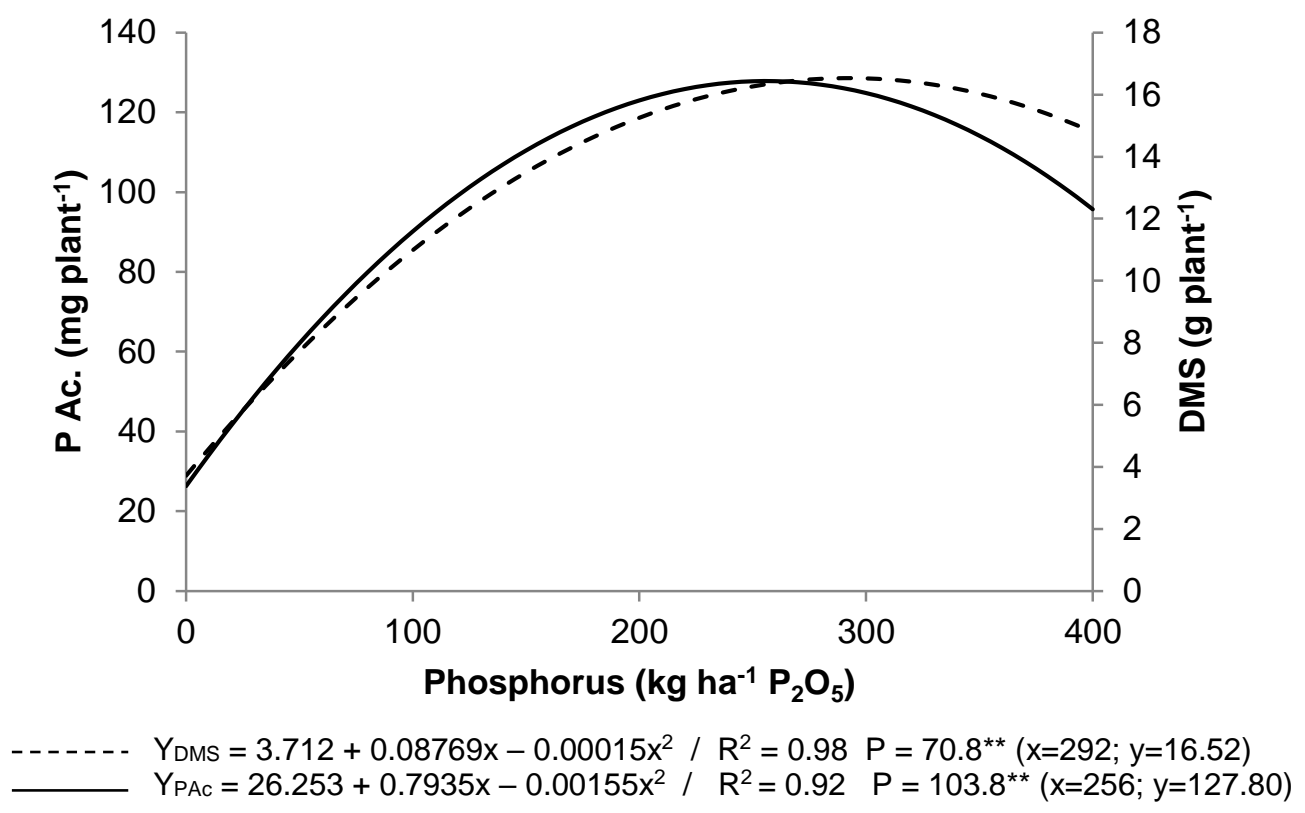

Figure 2 - Dry mass of shoots (YDMS) and phosphorus accumulation (YPAC) on plants of lettuce 'Vera' depending on the dose of phosphorus.

The doses to maximize FMS and DMS were lower than those obtained by McPharlin and Robertson (1997), Mota et al. (2003) and Coutinho et al. (2008), who observed maximum yield of lettuce with high phosphorus levels, above $600 \mathrm{~kg} \mathrm{ha}^{-1} \mathrm{P}_{2} \mathrm{O}_{5}$. The divergence of the results obtained and reported by the authors may be due to the many environmental factors, especially of the soil - such as mineralogy, $\mathrm{Fe}$ and $\mathrm{Al}$ oxides content, $\mathrm{pH}$, organic matter and available $\mathrm{P}$ content (Hue, 1991; Anghinoni \& Bissani, 2004) -, interacting with the cultivar of lettuce.

The dose of $283 \mathrm{~kg} \mathrm{ha}^{-1} \mathrm{P}_{2} \mathrm{O}_{5}$, which afforded maximum FMS of the lettuce 'Vera', is lower than the dose of $400 \mathrm{~kg} \mathrm{ha}^{-1} \mathrm{P}_{2} \mathrm{O}_{5}$ recommended by Trani et al. (1997) for lettuce, when the $P$ content in the soil is low.

The DMS obtained in this study was similar to that obtained by Costa et al. (2007), in Jaboticabal, SP, with the crisp leaf lettuce 'Vera', with $16.61 \mathrm{~g} \mathrm{plant}^{-1}$, and lower than that obtained by Bonela (2010), also in Jaboticabal, in Oxisol with high content of the nutrient, who found DMS of 21.5 g plant $^{-1}$, with $300 \mathrm{~kg} \mathrm{ha}^{-1} \mathrm{P}_{2} \mathrm{O}_{5}$, for the cultivar 'Amanda', from the crisp leaf group. However, it exceeded those found in 'Veronica' lettuce, fertilized with $60 \mathrm{~kg} \mathrm{ha}^{-1} \mathrm{P}_{2} \mathrm{O}_{5}$, in the northeastern semi-arid, with an average of $6.4 \mathrm{~g} \mathrm{plant}^{-1}$ (Grangeiro et al., 2006).

To obtain $90 \%$ of the maximum FMS (Figure 1), $184 \mathrm{~kg} \mathrm{ha}^{-1}$ of $\mathrm{P}_{2} \mathrm{O}_{5}$ were necessary, therefore, $99 \mathrm{~kg} \mathrm{ha}^{-1}$ of $\mathrm{P}_{2} \mathrm{O}_{5}$ less than the dose that afforded maximal production. Without application of $\mathrm{P}$ were obtained the lowest FMS and DMS, 150 and $3.7 \mathrm{~g}$, respectively (Figures 1 and 2), equivalent to 17.5 and $22.4 \%$ of the maximum FMS and DMS.
According to Coutinho et al. (2008), the lettuce is not a plant adaptable to soils with low availability of nutrients in the topsoil.

According to the polynomial equations for FMS, leaf $P$ content and $P$ content in soil (Figure 1), for producing 90 to $100 \% \mathrm{FMS}$, the $\mathrm{P}$ content in soil and leaf were 55 to $60 \mathrm{mg} \mathrm{dm}^{-3}$ and 6.1 to $6.4 \mathrm{~g} \mathrm{~kg}^{-1}$, respectively, while for producing between 70 and $90 \%$ of the maximum FMS, $\mathrm{P}$ contents in the soil were between 45 and $55 \mathrm{mg} \mathrm{dm}^{-3}$ and in the leaf were between 6.0 and $6.4 \mathrm{~g} \mathrm{~kg}^{-1}$. Levels of $P$ in the soil lower than $45 \mathrm{mg} \mathrm{dm}^{-3}$ and with less than $6 \mathrm{~g} \mathrm{~kg}^{-1}$ provided less than $70 \%$ of the maximum FMS.

At the dose that provided 100 and $90 \%$ of the maximum FMS of the lettuce, the accumulation of $P$ was 127 and $120 \mathrm{mg} \mathrm{plant}^{-1}$. This is similar to the amount obtained by Grangeiro et al. (2006), who observed $110 \mathrm{mg} \mathrm{plant}^{-1}$ lettuce.

Considering $6,250 \mathrm{~m}^{2}$ of area of planting beds in one hectare cultured with lettuce, planted in spacing of $0.3 \times 0.3 \mathrm{~m}\left(69,444\right.$ plants ha- $\left.{ }^{-1}\right)$, there is export of $8.8 \mathrm{~kg} \mathrm{ha}^{-1}$ of $\mathrm{P}$, or $20 \mathrm{~kg} \mathrm{ha}^{-1}$ of $\mathrm{P}_{2} \mathrm{O}_{5}$.

\section{Conclusions}

In Ultisol with low phosphorus availability, lettuce responds positively to phosphorus fertilization, requiring $283 \mathrm{~kg} \mathrm{ha}^{-1} \mathrm{P}_{2} \mathrm{O}_{5}$ to maximize the productivity of fresh mass of shoots of the plants.

\section{References}

Anghinoni I, Bissani CA (2004) Correção da acidez do solo e materiais utilizados. In: Bissani CA, Gianello C, Tedesco MJ, Camargo FAOC. Fertilidade dos solos e manejo da adubação de culturas. Porto Alegre: Gênesis, cap.12, p.153-165. 
Almeida TBF, Prado RM, Correia MAR, Puga AP, Barbosa JC (2011) Avaliação nutricional de alface cultivada em soluções nutritivas suprimidas de macronutrientes. Revista Biotemas 24(2):27-36.

Bataglia OC, Furlani AMC, Teixeira JPF, Furlani PR, Gallo JR (1983) Métodos de análise química de plantas. Campinas: Instituto Agronômico, Campinas.41p. (Boletim Técnico, 78).

Bonela GD (2010) Adubação fosfatada e potássica para alface em Latossolo com teores altos de $\mathrm{P}$ e K disponíveis. 69p. Dissertação (Mestrado em Ciência do Solo) - Faculdade de Ciências Agrárias e Veterinárias, Universidade Estadual Paulista, Jaboticabal, 2010.

Costa CC, Cecílio Filho AB, Rezende BLA, Barbosa JC, Grangeiro LC (2007) Viabilidade agronômica do consórcio de alface e rúcula, em duas épocas de cultivo. Horticultura Brasileira 25(1):34-40.

Coutinho ELM, Carvalho FP, Franco HCJ, Orioli Júnior V, Coutinho Neto AM, Ueta FZ (2008) Adubação fosfatada em cultivares de alface cultivada em solos deficientes. Nucleus 5(2): 279-288.

EMBRAPA - EMPRESA BRASILEIRA DE PESQUISA AGROPECUÁRIA (2013) Sistema brasileiro de classificação de solos. 3.ed. Brasília. 353p.

Faquin V, Andrade AT (2004) Nutrição mineral e diagnose do estado nutricional de hortaliças. Lavras: UFLA/FAEPE, 88p.

Grangeiro LC, Costa KR, Medeiros MA, Salviano AM, Negreiros MZ, Bezerra Neto F, Oliveira SL (2006) Acúmulo de nutrientes por três cultivares de alface cultivadas em condições do Semi-Árido. Horticultura Brasileira 24(2):190-194.

Guppy CN, Menzies NW, Moody PW, Blamey FPC (2005) Competitive sorption reactions between phosphorus and organic matter in soil: a review. Australian Journal of Soil Research 43:189-202.

Hartz TK, Johnstone PR (2007) Establishing lettuce leaf nutrient optimum ranges through DRIS analysis. Hortscience 42(1):143-146.

Hochmuth G, Hanlon E, Nagata R, Snyder G, Shueneman $T$ (2009) Fertilization recommendations for crisphead lettuce grown on organic soils in Florida. Horticultural Sciences Department, Florida Cooperative Extension Service, Institute of Food and Agricultural Sciences, Flórida: University of Florida. 14p. Disponível em: < http://edis.ifas.ufl.edu/pdffiles/HS/HS115600.pdf>. (Acesso em: 29 nov. 2012).
Hue NV (1991) Effects of organic acids/anions on phosphorus sorption and phytoavailability in soils with different mineralogies. Soil Science 152(6):463-471.

Johnstone PR, Hartz TK, Cahn MD, Johnstone MR (2005) Lettuce response to phosphorus fertilization in high phosphorus soils. HortScience 40(5):1499-1503.

Lana RMQ, Zanão Júnior LA, Luz JMQ, Silva JC (2004) Produção da alface em função do uso de diferentes fontes de fósforo em solo de Cerrado. Horticultura Brasileira 22(3):525-528.

Luchini I, Tiritan CS, Foloni JSS, Santos DH (2012) Fósforo disponível em solos ácidos e corrigidos com aplicação de fosfatos solúvel, reativo e natural. Scientia Agraria Paranaensis 11(1):82-94.

McPharlin JR, Robertson WJ (1997) Response of spring-planted lettuce (Lactuca sativa L.) to freshlyapplied and residual phosphorus and to phosphate fertilizer placement on a Karrakatta sand. Australian Journal of Experimental Agriculture 37(6):701-708.

Mógor AF, Câmara FLA (2009) Teores de fósforo, potássio e produção de alface orgânica em diferentes coberturas do solo. Bioscience Journal 25(3):112-118.

Mota JH, Yuri JE, Resende GM, Oliveira CM, Souza RJ, Freitas SAC, Rodrigues Júnior JC (2003) Produção de alface americana em função da aplicação de doses e fontes de fósforo. Horticultura Brasileira 21(4):620-622.

Petrazzini LL, Souza GA, Rodas CL, Emrich EB, Carvalho JG, Souza RJ (2014) Nutritional deficiency in crisphead lettuce grown in hydroponics. Horticultura Brasileira 32(3):310-313.

Raij B (1991) Fertilidade do solo e adubação. Piracicaba: Potafós. 343p.

SBCS - SOCIEDADE BRASILEIRA DE CIENCIA DO SOLO (2004) Manual de adubação e de calagem para os Estados do Rio Grande do Sul e Santa Catarina. 10 ed. Porto Alegre. 400p.

Souza RF, Faquin V, Torres PRF, Baliza DP (2006) Calagem e adubação orgânica: influência na adsorção de fósforo em solos. Revista Brasileira de Ciência do Solo 30(6):975-983.

Souza PA, Negreiros MZ, Menezes JB, Bezerra Neto F, Souza GLFM, Carneiro CR, Queiroga RCF (2005) Características químicas de alface cultivada sob efeito residual da adubação com composto orgânico. Horticultura Brasileira 23(3):754-757. 
Tosta MS, Borges FSP, Reis LL, Tosta JSMV, Tosta PAF (2009) Avaliação de quatro variedades de alface para cultivo de outono em Cassilândia - MS. Agropecuária Científica no Semi-árido 5(1):30-35.

Trani PE, Passos FA, Azevedo Filho JA (1997) Alface, almeirão, chicória, escarola, rúcula e agrião d'água. In: Raij B, Cantarella H, Quaggio JA, Furlani AMC. Recomendações de adubação e calagem para o estado de São Paulo. Campinas: IAC. p.168. (Boletim Técnico, 100).
Trani PE, Raij B (1997) Hortaliças In: Raij B, Cantarella H, Quaggio JA, Furlani AMC. Recomendações de adubação e calagem para o Estado de São Paulo. Campinas: IAC. p.157-163 (Boletim Técnico, 100).

Villas Bôas RL, Passos JC, Fernandes M, Büll LT, Cezar VRS, Goto R (2004) Efeito de doses e tipos de compostos orgânicos na produção de alface em dois solos sob ambiente protegido. Horticultura Brasileira 22(1): 28-34. 